\title{
Islamic Financial Development as Efforts to Accelerate Economic Development and Poverty Alleviation
}

\author{
Elsi Mersilia Hanesti \\ Master of Islamic Economics Science- \\ Postgraduate Program \\ Universitas Airlangga \\ Surabaya, Indonesia \\ Email: elsimerhan@gmail.com \\ Mobile: +62 88226150943
}

\author{
Sri Herianingrum \\ School of Islamic Economics - \\ Postgraduate Program \\ Universitas Airlangga \\ Surabaya, Indonesia \\ Email: sriheria@yahoo.co.id \\ Mobile: +62 81938619426
}

\author{
Raditya Sukmana \\ School of Islamic Economics - \\ Postgraduate Program \\ Universitas Airlangga \\ Surabaya, Indonesia \\ Email: momyadit@gmail.com \\ Mobile: +62 87854216776
}

\begin{abstract}
Economic development is one of the most important things in relation to the achievement of a successful economy in a country. One of the achievements of economic development is poverty alleviation. But, in the process of economic development, there are many imbalances. From the various types of inequality that occurred during the economic development process, it can be concluded that these imbalances occur because of the imbalance in the achievement of economic development, namely between the monetary and real sector. Nowadays, there are two concepts of economic development (capitalism and socialism economic). Since 1991, Islamic economy has been applied in Indonesia. It is not only about Islamic banking, but also Islamic finance, Islamic insurance, Islamic capital market, and Islamic development. The capitalism or socialism economy concept does not always offer the effective and efficient concept as expected in the development process. Then, what about an Islamic economy? Using an in-depth study literature method, it has been found that the Islamic financial system is able to answer the imbalance in the economic development process, particularly in terms of distribution that is comprehensive and consistent with the goals and objectives of the Millennium Development Goals (MDGs).
\end{abstract}

Keywords: Islamic Financial Development, Millennium Development Goals (MDGs), Poverty, Distribution.

\section{INTRODUCTION}

Poverty is one part of the economic development process. In general, poverty is a condition in which a person is unable to fulfil their own needs (Huda, 2015: 23). In fact, the reality of poverty is not only experienced by developing and underdeveloped countries, but developed countries are also inseparable from this problem. In fact, statistically, a country with high economic growth often has an increased poverty rate. For example, Brazil and England.
From here, it can be said that there is an imbalance in the development process that has been going on to date, where economic growth is a major indicator in the process of economic development and poverty alleviation is one of the goals of economic development.

In the field, there are two concepts of economic development that have been used by countries around the world. The two concepts of economic development are the economic development of Capitalism (classical) and the economic development of Marxism (radical). Both conventional economic development concepts use economic growth as an indicator of success. Not only developed countries, but developing countries also use both concepts of economic development. Although it looks different, in principle, both ideologies have in common, among others: the belief that natural resources are the object of the development process and that natural resources are limited to meet human needs (scarcity of resources and unlimited needs). Another equation is that humans as development actors are positioned as economic beings and the purpose of economic development for both of these ideals is to maximise production and consumption.

Millennium Development Goals (MDGs) are a declaration that focuses on the problem of poverty in the world that has been agreed by the Heads of State of the 189 UN member states that began in September 2000. The main focus of the MDGs is to eradicate poverty and starvation. To overcome the problem of poverty, the government and stakeholders must first know the root causes of poverty. Poverty is a condition where there is inequality in the wealth distribution process generated by a country, where the wealth of this country is manifested in the total production in the country or total gross domestic product (GDP) in association with economic growth. The higher the total production that can be produced by a country, then the society should be more prosperous because the total production is able to meet the needs of all members of society, especially basic needs such as food, clothing, and 
board. But the fact is not so, and so has emerged the condition of poverty.

The Islamic economic system has recently begun to deal specifically with the development system. It covers not only economic and financial aspects. In principle, the economic system that has existed since the time of the leadership of Prophet Muhammad SAW has covered all aspects of human life, ranging from social life (moral) through to worship (spiritual), economic, political, which further leads to development more comprehensively. In the financial system alone, there is a linkage of values and financial practices with the development process. Of course, what is expected is a system of development that can be implemented by all countries, not like the two economic systems that have been running. The financial system is one of the most crucial things in the process of economic and human development. This article will discuss the concept of development in Islam and further develop a model of development in relation to Islamic values that are universal, applicable to all countries and without any particular religious discrimination.

\section{LITERATURE REVIEW}

\section{A. The Paradigm of Conventional and Islamic Economic Development}

There are two philosophies of economic development that have been applied interchangeably throughout, both in developing and developed countries. They are the philosophies of Capitalism and Marxism. The two philosophies have been mutually replaced as a result of the theory of the philosophy of economic development stating that one is not efficient enough, so it is replaced by other economic development philosophy theories. Both theories of the development of Capitalism and Marxism use economic growth as an indicator of the success of the economic development process. Thus, in the discussion of both economic development theories, it will use the term economic growth and economic development in turn. For both of these paradigms, economic development is identical to the process of increasing national production and increasing income per capita, both of which serves as a proxy for an increase in economic growth. The economic development theory of Capitalism is the result of classical economists' ideas: Adam Smith, Ricardo, Malthus, and Lewis. The classicalist's thinking produced a liberalcapitalist economic and development system. At this time, there was a very famous works of Adam Smith called The Wealth of Nations. Furthermore, economic development by way of Marxism is the result of Karl Marx's thought. Karl Marx's thinking produced a socialist-communist economic and development system. However, Karl Marx's thinking did not long last and re-used capitalism's theory; the socalled Neoclassical Era (the rise of the classical view). Later also emerged the development theories of modern economists.
On the other hand, the paradigm of Islam regarding the development concept is broader than the conventional development paradigm. The paradigm of development in Islam is a multidimensional development, which means development in all dimensions, namely: moral, social, economic, political, and even the conservation of natural resources (Mannan in Huda, 2015: 21). Islamic development theory is focused on the moral and spiritual role which is further integrated with economic development, so that it can be achieved in terms of both material and nonmaterial development.

\section{B. Millennium Development Goals (MDGs)}

Millennium Development Goals (MDGs) is a declaration that focuses on the problem of poverty in the world. This declaration was the result of the consensus of state heads from 189 United Nations (UN) members. It was approved and commenced in September 2000. MDGs are an international commitment or declaration to achieve tangible progress in global poverty reduction efforts and to achieve the goal of overall economic development. MDGs use the same concept in Islamic development, namely that the process of development and poverty reduction must be multidimensional, not only by raising the income of the poor but also covering all of the related aspects. The main focus of the MDGs is to eradicate extreme poverty and hunger. The MDGs provide consultation facilities for countries, especially underdeveloped and developing countries. This facility is expected so that countries can issue and discuss all of the problems that exist in their country. In addition, MDGs also invite developed countries to achieve their objectives by encouraging them to increase the amount of aid funds, to eliminate trade and investment barriers, and to eliminate debts that the poorest countries cannot pay (Huda, 2015: 87 and www.un.org). There are eight points agreed upon in the MDG declaration:

a. Tackling poverty and hunger

b. Achieve universal primary education

c. Encourage gender equality and to empower women

d. Reduce child mortality

e. Improve maternal health

f. Fighting HIV/AIDS, ague, and other infectious diseases.

g. Ensure environmental sustainability

h. Develop a global partnership for development

\section{METHODOLOGY}

The methodology used in this article was a literature review that discusses and analyses topics based on the references used in this study (Abdullah, 2014: 213). The data used in this research was data documentation, namely: reference books, journals, previous studies, articles, and the latest news from reliable sources related to the development of financial systems and economic growth. In addition, the discussion in this study was reinforced by examining the opinions of Islamic economists on the relationship of 
Islamic financial development and the economic growth of a country.

\section{DISCUSSION \\ A. Paradigm of Islamic Development and Islamic Tasawwur}

Salleh (2009: 13) mentioned that there are seven basic principles of Islamic development, namely: the basic reference of development, development actors, development time scale, development framework, developmental methods, development tools, and development goals.

What distinguishes most fundamentally the philosophy of Islamic development from the conventional development philosophy lies in the paradigm (basic reference or worldview) used as a guideline for its implementation. Although different, the philosophy of capitalism and Marxism come from a common paradigm, namely the Western paradigm. The disadvantage is that the culture, traditions, operational systems, and problems in each country must be different from those in the West, especially in developing or underdeveloped countries and Eastern countries where their life is very different from the developed countries of the West. With the application of Western development theory, the cultures in each country are required to implement Western culture and this will gradually erase the country's original culture. This is unlike Islamic development theory. The philosophy of Islamic development theories uses a paradigm of Islamic law itself. There are four sources of Islamic law and science, that is: the Qur'an, Hadith, Ijma, and Qiyas. The sources of Islamic law and science are universal. These four sources of Islamic law ultimately form an Islamic paradigm called Tasawur in Islamic (Salleh, 2009: 17). Tasawwur Islam is used as the basis of the development process in Islam that is multidimensional. The principles of Islamic tasawwur describe Islamic principles as complete and comprehensive. Not only does it explain the concept of faith, but it also describes the concept of other life. One of these concepts is the concept of development. In tasawwur Islam, there are three main principles, namely: that Allah SWT is the Creator, human beings are His creation, and natural resources are His creatures.

\section{B. The Concept of Poverty in Islamic Development}

As explained above, the paradigm of Islamic economic development is very different from the paradigm used in conventional economic development. Similarly, is the perspective of Islamic development on poverty.

In the contemporary approach, there are three perspectives on the causes of poverty, namely (Huda, 2015: 10): first, they are poor because they are ignorant, lazy, not tenacious, and have no sense of achievement; second, they are poor because of the lack of opportunities to improve their lives and third, they are poor because of the structure of society where there is a small group of rich and powerful members of society, while the other members are poor. The first approach is the forerunner to the theory of capitalism, while the third approach is the forerunner to the theory of Marxism.

Capitalists perceive that poverty poses a problem to be solved by the poor themselves, while the rich are free to use their wealth. Marxists claim that poverty will be resolved if the bourgeoisie and its wealth are not destroyed, but organised into new classes. Whereas in Islam, poverty has a broader definition. Al-Ghazali (1980) and Ahmed (2004) divide poverty into two types, namely: material poverty and spiritual poverty (Huda, 2015: 23). Chapra in Huda (2015: 23) also states that Islam places the same emphasis on both spiritual and worldly affairs. Islam sees poverty as a thing that can endanger morals, logical thinking, family, and also society at large. Qardhawi in Huda (2015: 25) mentions there are three groups of experts in viewing poverty, namely: first, that poverty is not a problem to be solved, but it must be allowed; Second, that poverty is a destiny of Allah SWT and human beings must patiently face the test and third, as well as the second group and individually, the community must help the poor.

The discussion of the solution of poverty is the need to understand two aspects that are at the root of the poverty problem. First, society needs to understand the boundaries between needs and wants. There is a wrong mindset brought about to do with poverty by Capitalism and Marxism. There are many erroneous assumptions that are believed in both conventional development theories and that have been widely believed by society. One is the assumption that human needs are infinite. In general, there are three levels of needs, namely: primary, secondary, and tertiary needs. In Islam, there are also described three levels of needs, namely: dharuriyyat, hajjiyat, tahsiniyat. To survive, every human being must be able to meet their basic needs, that is the primary need or dharuriyyat needs. It has been explained that the primary needs consist of food needs, clothing, and board (housing). Thus, the three basic needs are in accordance with the standards that must be met by each individual. Both of the other types can be met when there is excess income. It is clear that human needs are limited. Not an unlimited need, but unlimited wants. Every human being has a lust, in which one of them is in the form of desire. Desire and lifestyle is what makes every man always want to have what he wants. Encouragement to always fulfil this desire will actually make people out of control in managing their finances and this can lead to poverty. Someone is said to be poor if they are unable to meet his own needs. The inability to fulfil what is not needed is not called poverty.

Second, from the statistical data, it is seen that high poverty rates are in line with high growth rates. Economic growth is not wrong, just that there is a something missing resulting in economic growth that cannot be felt by the whole community, so it causes the problem of poverty. The main 
key to this problem is the inequality of income distribution. Inequality of income distribution is what eventually leads to economic growth that cannot be felt by the whole of society equally.

\section{Islamic Financial Development Model in Achieving MDGs and Poverty Alleviation}

In general, there are two ideologies related to the Islamic financial system, namely: liberalist and fundamentalist (Fajri, 2008). Liberalists state that interest banks are not classified as usury (riba) because the meaning of usury is the very high reduplication of money. Meanwhile, the second ideology states that interest banks are usury. Nevertheless, banks and other financial institutions are not prohibited, or even required. Banks and other financial institutions are not based on interest, but use the financial system that is based on a sharing system (profit and loss sharing). There are three Islamic financial institutions that support the development of the Islamic economic system in various Islamic countries in the world in general, namely: banking industry, non-banking industry, and micro-finance institutions. These three Islamic financial institutions have their own functions and roles in relation to supporting the economic growth and development in a country.

Development in a region includes not only economic development. Comprehensive development also includes the development of health, education and society (multidimensional). In order to generate development in all aspects of life, it is necessary to have development strategies in each region in synergy.

At the international level, there are many established institutions, organisations, and programs to achieve economic development that is universal to all countries. One of them is the declaration of the Millennium Development Goals (MDGs). Millennium Development Goals (MDGs) are a declaration that focuses on the problem of poverty in the world that has been agreed on by the heads of state of the 189 UN members that began in September 2000. The main focus of the MDGs is to eradicate poverty and starvation. The MDGs apparently use the same concept in Islamic development, namely that the process of development and poverty reduction must be multidimensional, not only by raising the income of the poor but covering all of the related aspects. To overcome the problem of poverty, the government and stakeholders must first know the root cause of this poverty. Poverty is a condition where there is inequality in the wealth distribution process generated by a country, where the wealth of the country is manifested in the form of the total production in the country or the total gross domestic product (GDP). The higher the total production that can be produced by a country, then the society should be more prosperous because the total production is able to meet the needs of all members of society, especially their basic needs such as food, clothing, and boards. This fact is not so, so there arises a condition of poverty.

The development of Islamic finance is a term that refers to the growth and development of Islamic finance not only in terms of the quantity of Islamic financial institutions and the amount of market share, but also in terms of the quality of products, regulations and institutions. One of the Islamic financial instruments that has the function of being a facilitator of the distribution of wealth generated by the state is zakat and cash waqf. Not only does this serve as a means of distribution, but zakat and cash waqf also serve to redistribute wealth in society.

Figure 1 illustrates a model as well as the national development cycle supported by the development of Islamic finance. The development of Islamic finance which is meant here is not only financial development in terms of th quantity of products and institutions, but it is also related to an increase in terms of quality; both the quality of the product, institutional (institution), as well as the regulations governing Islamic finance. Figure 1 also shows the development strategies to be achieved. Each of these development strategy posts has a link with each other. As a first step, the government should be able to guarantee the health of its people by providing easy access to ensure the health of the entire community. Ensuring the availability of adequate health facilities and not burdensome health costs is important, especially for lower-income communities. The health aspect will be directly related to the availability of halal, healthy, clean, and nutritious food. It is desirable that the fulfilment of food needs comes from domestic food production and to reduce imported food to a minimum. When the community has been guaranteed their health and food, then the process of providing education can run more smoothly. The government also needs to reconstruct the existing education system.

The educational system is expected to be an education system that can be reached by all Indonesian people, both in terms of quality and quantity. When the development of the field of education has been achieved, the next step is the availability of jobs for the labour force which is supported by the provision of training and coaching, so that people do not only have the hardskill qualities of their course, but also the quality of soft skills. The availability of employment and skills training is not only the task of the government, but the community is also expected to create jobs for other communities widely. It is expected that the government support for job creation is not a hindrance, such as high taxation and so forth. The availability of employment and skills training will create activity in the real sector, where the real sector can go on to sustain the Indonesian economy. Concepts that are discussed in this article are the importance of development in the real sector to create overall development in all aspects of human life (multidimensional). Here is the flow chart of the 
development model of the Islamic economic concept that the authors propose.

All production activity in the real sector will definitely need an injection of capital from investors, the company itself, and the government. When the real sector activity increases, the production rate will increase as well, so that the basic needs of society as a whole (food, clothing, and shelter) are met. Furthermore, it is certain that national development can be achieved. National development is reflected in the Human Development Index (HDI), which also includes: income, health, and education. In Islamic economics, indicators of the success of national development can not only be seen from HDI, but it also needs to be supported by the welfare of society being met, both globally and in the hereafter (Falah).

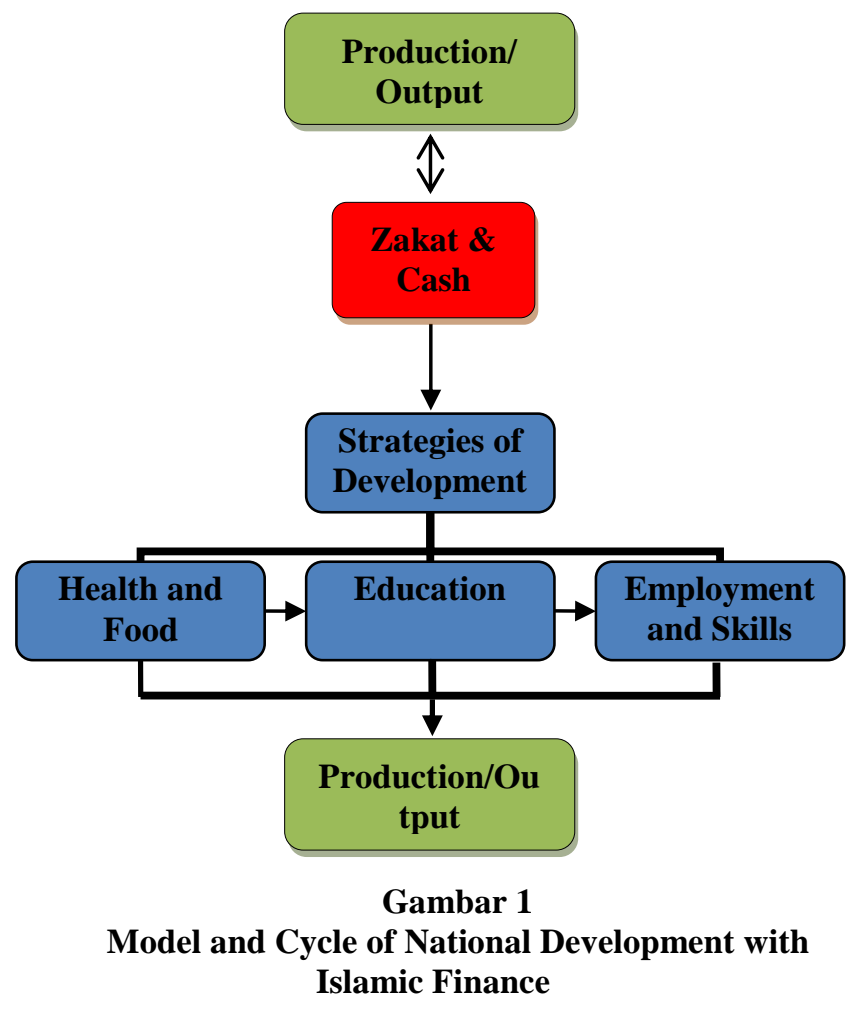

As mentioned above, the main factor needed to utilise the real sector is the availability of capital for producers to be able to process raw natural resources into a product of innovation to meet the needs of people living widely. This is where it takes on the function and role of the government to provide capital and to provide easy access to capital for producers. The real sector in question is in the form of SMEs (Small and Medium Enterprises), agriculture sector, trade, plantations, fisheries, home industry, technology and so forth. The types of sources of capital include: from the government and from private or their own funds. The Islamic economic and financial system has Islamic financial instruments where the source of capital is a broad set of societies to assist other communities capable of processing and producing goods and services. It can be seen that the
Islamic economic system is a system of people making an economy by embracing community togetherness and fraternity (brotherhood) (Mujahidin, 2007: 37). People are not walking alone, but working together. The forms of Islamic financial instruments are diverse. Two of them are the main sources of accumulation in Islamic finance, namely: zakat and waqf (Beik, 2016: 182). There are two types of zakat, namely: zakat fitrah and zakat maal. There are also two types of waqf, namely: physical waqf and cash waqf. In this paper, the discussion will focus on the use of zakat and cash waqf as a solution to food security and poverty alleviation which in turn leads to economic development that is multidimensional. The author proposes a new model for cash waqf that could be applied in the fight against poverty as goals to be achieved in the declaration of MDGs. As mentioned above, food and health are fundamental and at the same time, a major problem in Indonesia. Major community welfare begins with the people's ability to survive, by accessibility to food. But if you look at the facts that exist in today's society, the food situation in Indonesia has been very controversial, where Indonesia has a smorgasbord of natural resources that are abundant but there are still many Indonesian people who experience food imbalance and are below the poverty line. This food imbalance becomes one of the elements of poverty. This is more so with the large-scale import policy taken up by the government. Import activity from year to year has increased.

Various literatures and facts about food can be used to conclude that, in fact, there are only two factors that underlie the problem of food needs in Indonesia, namely: the procurement and distribution of food. The procurement of food is related to the availability of food supply in the community. Food procurement can be optimised by optimising the existing resources as production factors. These resources include natural resources and human resources as the principal organiser. Many methods have been done by the economic system that has been running so far to ensure the availability of food in Indonesia.

Food availability is the result of the viewpoint used in resource ownership. Resource ownership (which in turn implies the right of management) is a key element in regulating the economy. In the capitalist system, resources come under private ownership. In a socialist system, the resources come under state ownership. In the Islamic economic system, the principle of ownership of the resource is multi-species (multiple ownership) (Mujahideen, 2007: 24). That is, the Islamic economic system recognises private, state, and mixed ownership. This relates to the value of monotheism where everything on this earth is the sole property of Allah. Man, as the only representative of Allah, is the temporary owner. Thus, resources cannot be owned absolutely by the private sector or by the state. Natural resources are gifts from Allah, in which Allah has guaranteed the availability of natural resources for each man 
and man is given the right to use it optimally without exploitation. There are several resources that must be managed by private, state, or mixed ownership. Production resources concerning the livelihood of the people are taken over into state ownership. This is intended to protect and maintain the welfare of the community (justice), including one of which is the interest of food fulfilment.

Here, the government is expected to play its role in regulating the production resources related to the livelihood of the people. One of the main factors is the provision of capital or subsidies to rice and sugar producing companies and cattle and poultry farmers, where the supporting production factors require quite expensive costs such as technology, animal feed, and others. See the main problem; the Islamic economic system offers a system of zakat and waqf capital through cash that has actually been done since the time of Rasulullah SAW to khalifahan.

From the picture of the development model proposed by the author above, it can be seen that zakat and cash waqf has two functions at once. First, zakat and cash waqf are a source of capital for each post-economic development, including: development in the health and food sector, education sector, and social sector (providing sufficient employment to cope with unemployment). Furthermore, the expected goal that can be achieved is poverty alleviation that is multidimensional. Poverty reduction that is multidimensional means that not only is there an increase per capita income levels, but also it alleviates poverty in all aspects. The distribution and utilisation of zakat funds and cash waqf is not only channelled for consumptive purposes, but also productive (productive zakat and productive waqf) purposes. Thus, the benefits of the distribution and utilisation of zakat and waqf are perceived not only today but also in the long term (Darwanto, 2012 and Haq, 2012).

Second, zakat and waqf of cash are a tool that serves to distribute better production (output) to all members of society in a fair and equitable manner. Apart from being a distribution tool, zakat and cash waqf have an additional function that is as a tool to redistribute the production (Maya, 2011 and Muhyar, 2011). This is done to property, wealth, or production in a country that is not only channelled to people who can afford it; it is expected that the yields can be felt by all members of society, as mentioned in QS. Al-Hashr (59): 7.

"..... so that it may not circulate between the rich among you. What the Apostle gave you, so please accept it. "

With the accumulation of wealth, the poverty problem can be resolved. This stockpiling of property is the cause of poverty (the economy becomes static), where the wealth can only be enjoyed by the elite. As mentioned above, poverty occurs because there is no chance for the poor to improve their lives.
Besides zakat and cash waqf instruments, there are still other Islamic financial instruments which have a dual function as in the model. Islamic financial development is not only a means of distribution, but it is also a tool for capital. Beside zakah and cash waqf, the Islamic economic system has a micro-finance system as a tool to increase human well-being and to help humans fulfil their needs. Micro-finance in the Islamic economic system is different to others. The concept of Islamic microfinance is mutual help. There are two types of micro-finance in the Islamic economy, that is commercially-oriented micro-finance and non-commercially-oriented micro-finance. The concept of micro-finance in conventional economic systems (capitalism and socialism) is only commercially-oriented. According to Montgomery and Weiss (2010), commercially-oriented micro=finance and the millennium development goals are not incompatible. Their research found that in rural areas, commercially-oriented micro-finance has a negative impact on food expenditure and on some social indicators such as the health of children and female empowerment. These indicators are some of the millennium development goals. This therefore agrees with Clements's findings (1993). Clement said that a country should create independent units (agencies) devoted exclusively to poverty alleviation. These units should immerse their staff totally in being socialoriented, not commercially-oriented.

\section{CONCLUSION}

Poverty is a condition where there is the inequality of the wealth distribution process generated by a country. To overcome the poverty problem, the government and stakeholders must first know the root cause of this poverty. The main cause of poverty is the inequity of wealth and resource distribution.

MDGs are an international commitment or declaration to achieve tangible progress in global poverty reduction efforts and to achieve the goal of overall economic development. MDGs use the same concept as Islamic development, namely that the process of development and poverty reduction must be multi-dimensional, not only by raising the income of poor but also by covering all of the related aspects. The paradigm of Islamic development is Tasawwur Islam. To alleviate poverty, Islamic financial development use zakat and cash waqf as intermediates, distribution tools and tools for capital.

\section{REFERENCES}

[1] Beik, Irfan Syauqi and Laily Dwi Arsyianti. 2016. Ekonomi Pembangunan Syariah. Edisi Revisi. Jakarta: PT RajaGrafindo Persada.

[2] Clements, Paul. 1993. An Approach to Poverty Alleviation for Large International Development Agencies. World Development Journal Vol 21, No. 10 pages 1633-1646, www.elsevier.com.

[3] Darwanto. Wakaf Sebagai Alternatif Pendanaan Penguatan Ekonomi Masyarakat di Indonesia. Jurnal Ilmu Manajemen dan Akuntansi Terapan. Vol. 3 Nomor 1, Mei 2012. 
[4] Haq, A. Faisal. Wakaf Kontemporer Dari Teori Ke Aplikasi. Jurnal Maliyah, Vol.2, No.2, Desember 2012.

[5] Huda, Nurul. 2015.Ekonomi Pembangunan Islam. Jakarta: Kencana.

[6] Fajri, Rahmat. Sejarah Keuangan Islam. APLIKASIA: Jurnal Aplikasi Ilmu-Ilmu Agama, Vol. IX, No 2 Desember 2008. Pg 173-194.

[7] Maya, Maimunah. 2011. Skripsi: Peran Wakaf Tunai Dalam Permberdayaan Usaha Kecil dan Menengah di Tabung Wakaf Indonesia. Jakarta: UIN Syarif Hidayatullah.

[8] Montgomery, Heather and John Weiss. 2010. Can Commercially-oriented Microfinance Help Meet the Millennium Development Goals? Evidence from Pakistan. World Development Journal Vol 39, No. 1 pages 87-109, www.elsevier.com.

[9] Muhyar, Fanani. Pengelolaan Wakaf Tunai. Jurnal Walisongo, Volume 19, Nomor 1, Mei 2011.

[10] Mujahidin, Akhmad. 2007. Ekonomi Islam: Sejarah, Konsep, Instrumen, Negara, dan Pasar. Jakarta: PT RAJAGRAFINDO PERSADA.

[11] Salleh, Muhammad Syukri. 2003. 7 Prinsip Pembangunan Berteraskan Islam. Kuala Lumpur: Zebra Editions Sdn.Bhd. 